\title{
Rice Husk Ash as Heterogeneous Silica-Based Catalyst Support for Palm Fatty Acid Distillate Conversion to Biodiesel
}

\author{
ZAINAB NGAINI ${ }^{1}$, Nurfarahen Jamil ${ }^{1}$, Rafeah Wahi ${ }^{1}$, Farra Shahrom ${ }^{1}$, and Zainal \\ Ahmad $^{2}$ \\ ${ }^{1}$ Universiti Malaysia Sarawak \\ ${ }^{2}$ Polytechnic Kuching Sarawak
}

July 9, 2020

\begin{abstract}
Rice husk ash (RHA) has potential as low-cost catalyst support to produce biodiesel. In this study, RHA was used as precursor for heterogeneous silica-based catalyst, Huskcatacid and Huskcatbase for biodiesel production from palm fatty acid distillate (PFAD). The formation of biodiesel from PFAD was performed via esterification using Huskcatacid, followed by transesterification using Huskcatbase. The biodiesel produced was evaluated based on several reaction parameters such as oil to methanol ratio, amount of catalyst, reaction times and temperature and the optimization of parameters was carried out. Results showed that Huskcatacid was efficiently employed in esterification of PFAD to afford 91.6\% ester in 1:1 (PFAD:MeOH) and 5 wt\% catalyst, followed by transesterification in 1:1 (oil: $\mathrm{MeOH}$ ) using Huskcatbase (1 wt\%) to produce $99.73 \%$ biodiesel in 30 min with high percentage of methyl palmitate (34.43\%) and methyl oleate (57.86\%). Both Huskcatacid and Huskcatbase have high porosity $(2.726 \times 10-3 \mathrm{~cm} 3 / \mathrm{g}$ and $4.985 \times 10-3 \mathrm{~cm} 3 / \mathrm{g})$ and surface area $(7.362 \mathrm{~m} 2 / \mathrm{g}$ and $14.493 \mathrm{~m} 2 / \mathrm{g})$, respectively, which offer efficient esterification and easy glycerol separation. The biodiesel obtained was applied on Megatechß-Mark III engine and demonstrated a proportional increased of torque (r) with the B100 biodiesel loading. Rice husk demonstrated a good potential as solid support heterogeneous catalysts and feedstock for value-added products, which also assists to overcome agricultural waste management issues.
\end{abstract}

\section{Hosted file}

Silica Manuscript JAOC revised.doc available at https://authorea.com/users/312341/articles/ 468287-rice-husk-ash-as-heterogeneous-silica-based-catalyst-support-for-palm-fatty-aciddistillate-conversion-to-biodiesel

\section{Hosted file}

Table.docx available at https://authorea.com/users/312341/articles/468287-rice-husk-ash-asheterogeneous-silica-based-catalyst-support-for-palm-fatty-acid-distillate-conversionto-biodiesel

\section{Hosted file}

Figure JAOC.docx available at https://authorea.com/users/312341/articles/468287-rice-huskash-as-heterogeneous-silica-based-catalyst-support-for-palm-fatty-acid-distillateconversion-to-biodiesel 